\title{
Responses of marine planktonic protists to amino acids: feeding inhibition and swimming behavior in the ciliate Favella sp.
}

\author{
Suzanne L. Strom ${ }^{1, *}$, Gordon V. Wolfe ${ }^{2}$, Kelley J. Bright ${ }^{1}$ \\ ${ }^{1}$ Shannon Point Marine Center, Western Washington University, 1900 Shannon Point Rd., Anacortes, Washington 98221, USA \\ ${ }^{2}$ Department of Biological Sciences, California State University Chico, Chico, California 95929-0515, USA
}

\begin{abstract}
Feeding rates of the tintinnid Favella sp. on the dinoflagellate Heterocapsa triquetra were inhibited by a number of dissolved free amino acids (DFAAs), with inhibition inversely proportional to the size of the amino acid side chain. The most inhibitory compounds (valine, cysteine, proline, alanine, and serine) reduced feeding to $<20 \%$ of the control rate at a concentration of $20 \mu \mathrm{M}$. Inhibition was dose-dependent, with a threshold of ca. $200 \mathrm{nM}$ for proline, and did not depend on ciliate feeding history (well-fed versus starved). Inhibition occurred rapidly $(<5 \mathrm{~min}$ after exposure) and was partially reversible upon removal of DFAAs. Detailed analysis of swimming did not reveal consistent changes in Favella sp. behavior upon exposure to inhibitory amino acids. In contrast to Favella sp., the heterotrophic dinoflagellate Gyrodinium dominans showed no feeding response to $20 \mu \mathrm{M}$ DFAAs, while the tintinnid Coxliella sp. exhibited reduced feeding (to approximately $50 \%$ of control rates) in response to a subset of the amino acids active in Favella sp. Our findings, along with the prevalence of some inhibitory compounds at $\mathrm{nM}$ concentrations in natural waters, point to a signaling function for these amino acids. Feeding deterrence in Favella sp. is, however, contrary to the typical attractant or stimulatory role of DFAAs, which has been documented for organisms ranging from bacteria to metazoans. The information content of the signal remains unclear but may be related to detection of prey quality during suspension feeding by Favella sp.
\end{abstract}

KEY WORDS: Chemical ecology · Signaling · Ingestion · Swimming behavior $\cdot$ Ciliate $\cdot$ Dinoflagellate

Resale or republication not permitted without written consent of the publisher

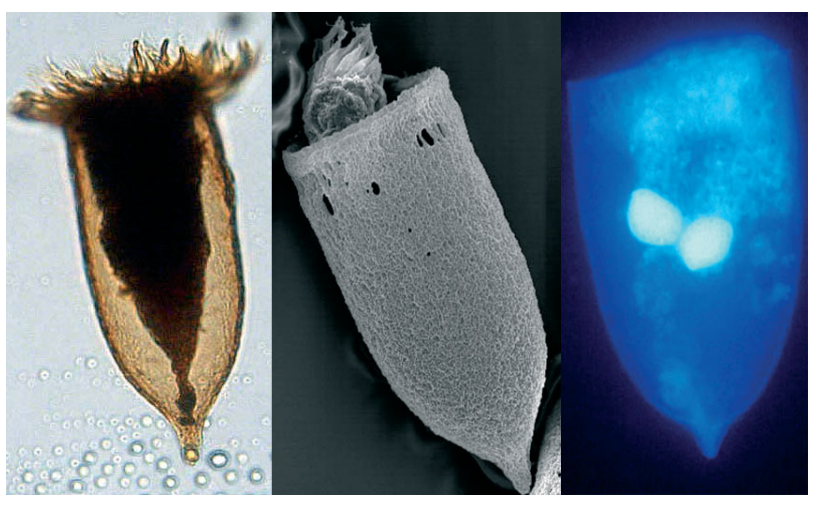

Feeding by the tintinnid Favella sp., a common coastal planktonic ciliate, is strongly inhibited by certain dissolved free amino acids. Feeding responses and swimming behavior indicate a signaling function for the inhibitory amino acids. Chemical signaling of this type affects predator-prey interactions in the ocean's microbial realm.

Photos: Gordon Wolfe

\section{INTRODUCTION}

Signaling among microbes can profoundly affect both individual behavior and community structure and function, as for example in the formation of biofilms (Pasmore \& Costerton 2003) or the recently discovered nitric oxide stress response in diatoms (Vardi et al. 2006). However, little is known about the role of signaling in regulating microbial predator-prey interactions in the ocean's planktonic realm (Wolfe 2000). Because much of the ocean's primary production is consumed by microbes, with major consequences for 
ocean biogeochemical cycles, it is important to understand processes such as chemical signaling that could regulate microbial interactions in the plankton.

The present research stems from our recent observation that feeding by free-living marine ciliates and heterotrophic dinoflagellates is inhibited by the organic osmolyte dimethylsulfoniopropionate (DMSP), a methionine derivative (Strom et al. 2003, Fredrickson \& Strom unpubl.). In addition, the dinoflagellate Amphidinium longum showed reduced feeding in response to some structural analogues of DMSP, including glycine betaine and N,N-dimethyl glycine. These results were unexpected since prior work on organisms from bacteria to fish has shown positive (e.g. attractant, feeding stimulant) responses to amino acids (e.g. Poulet \& Ouellet 1982, Levandowsky et al. 1984, Valentincic 1985, Miller et al. 2004).

DMSP and glycine betaine are non-toxic and present at high intracellular concentrations in numerous algae. They can be leaked or exuded into the environment by viable cells, particularly during stationary growth phase or when stressed (Matrai \& Keller 1994, Wolfe et al. 2002), though information on algal exudation is scarce. DMSP release has also been associated with grazing and viral lysis of DMSP-containing algal cells (Lee et al. 2003, and references therein). Such releases can produce gradients with concentrations reaching the nanomolar to micromolar range (Wolfe 2000). These concentrations reduced feeding by protists, a response that we postulated to be a signaling phenomenon rather than general metabolic inhibition or toxicity (Strom et al. 2003). Based on these findings, we suspected that other compounds with similar functions in the algal cell might also inhibit feeding in ciliates and dinoflagellates. DMSP is known to be an algal osmolyte (Kirst 1989) and is hypothesized to be an antioxidant (Sunda et al. 2002).

In this paper we explore the effects of a range of compounds, especially amino acids, on feeding responses and swimming behavior of protists. While the focus is on the tintinnid Favella sp., a genus of relatively large ciliates widely distributed in coastal seas (Pierce \& Turner 1993), we also studied an aloricate spirotrich ciliate and a heterotrophic dinoflagellate. We show that amino acids and the structurally related compounds betaine and DMSP inhibited feeding in the ciliates, but not in the dinoflagellate. Evidence that these are signaling compounds comes from numerous aspects of our data. However, the amino acid signaling response in Favella sp. is different in fundamental ways from that previously described for aquatic organisms including bacteria, protists, invertebrates, and fishes. The properties of the Favella sp. signaling response shed light on its possible adaptive significance.

\section{MATERIALS AND METHODS}

Chemical stocks and analyses. DMSP was obtained from Selact BV. All other chemicals were purchased from Sigma-Aldrich and were of the highest purity available. Amino acids were all L-enantiomers. Chemical stock solutions were freshly prepared in ultra-pure water ('Nanopure', purified by reverse osmosis, deionized, $0.2 \mu \mathrm{m}$ filtered) the day before each experiment and stored overnight at $4^{\circ} \mathrm{C}$. Addition volumes were $15 \mu$ unless otherwise indicated; control treatments received an equivalent volume of ultra-pure water.

Dissolved free amino acids (DFAA) were analyzed according to Parsons et al. (1984). All glassware was cleaned by soaking in base solution and combusting before use, then kept clean during the experiment by soaking in 0.25 M NaOH. Samples for DFAA analysis were filtered through precombusted $\left(450^{\circ} \mathrm{C}\right)$ glass fiber filters; the first few $\mathrm{ml}$ of filtrate from each sample were used to rinse the $20 \mathrm{ml}$ glass sample collection vial, the remaining volume was collected in the vial and stored frozen $\left(-70^{\circ} \mathrm{C}\right)$ until analysis. Separate standard curves based on the appropriate amino acid (serine, arginine) were prepared for each experimental treatment; glycine was used as the standard for analysis of DFAA samples from controls.

Culture methods. Heterotrophic protists used in this study included 2 tintinnid ciliates isolated from northern Puget Sound, Washington, USA: Favella sp. (SPMC101), and Coxliella sp. (SPMC110). The taxonomic status of the genus Coxliella is uncertain, since Favella sp. will produce Coxliella-form loricae when regrowing from the trophont (Laval-Peuto 1981). However, our culture produced exclusively Coxliella-form loricae during $4 \mathrm{mo}$ in culture. The heterotrophic dinoflagellate Gyrodinium dominans (SPMC103) was isolated from northern Øresund, between Denmark and Sweden (Hansen \& Daugbjerg 2004). All were maintained on prey mixtures at $15^{\circ} \mathrm{C}$ in filtered $(0.2 \mu \mathrm{m})$, autoclaved seawater (30 psu) with addition of a dilute trace metal mixture (henceforth 'ciliate medium'). Phytoplankton prey cultures were grown in f/2 without added $\mathrm{Si}$, prepared from 30 psu seawater. Phytoplankton were maintained at $15^{\circ} \mathrm{C}$ and approximately $50 \mu \mathrm{mol}$ photons $\mathrm{m}^{-2} \mathrm{~s}^{-1}$ in a $12: 12 \mathrm{~h}$ light:dark cycle. When used for experiments, phytoplankton cultures were in mid to late exponential phase.

Feeding rate measurements (general approach). Protist grazers were pre-starved unless otherwise stated. The ciliates Favella sp. and Coxliella sp. were separated from their maintenance prey by sieving through a $20 \mu \mathrm{m}$ mesh, followed by resuspension in fresh ciliate medium for $18 \mathrm{~h}$ (Favella sp.) or $4 \mathrm{~h}$ (Coxliella) before the start of the experiment. Gyrodinium dominans was starved by allowing the culture 
to deplete the prey over time. Immediately before each experiment, samples were taken to determine the 'background' level of prey in food vacuoles. As a percentage of the number of ingested cells per grazer in controls, these background levels were $\leq 2 \%$ for Favella sp., $12 \%$ for Coxliella, and $45 \%$ for G. dominans. For experiments, protist grazers were combined with fresh ciliate medium in $60 \mathrm{ml}$ polycarbonate bottles (4 per treatment); experimental volumes were $30 \mathrm{ml}$. Chemicals were added to $20 \mu \mathrm{M}$ unless otherwise indicated, and grazers were allowed to acclimate for variable amounts of time depending on the experiment. Phytoplankton prey cells were then added at

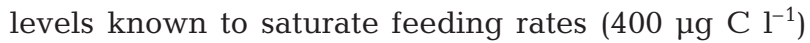
and grazers were allowed to feed for an appropriate time interval as determined in preliminary experiments (i.e. the mid-point of the vacuole filling time course). A $20 \mathrm{ml}$ aliquot from each experimental bottle was then added to cold $10 \%$ glutaraldehyde (final concentration $0.5 \%$ ) plus $4^{\prime} 6^{\prime}$ diamidino-2-phenylindole (DAPI stain, final concentration approx. $0.2 \mu \mathrm{g}$ $\mathrm{ml}^{-1}$ ). Preserved samples were stored at $4^{\circ} \mathrm{C}$ overnight, then filtered (polycarbonate filters: $5 \mu \mathrm{m}$ pore size for Favella sp., $1 \mu \mathrm{m}$ for other grazer species), slidemounted, and frozen $\left(-20^{\circ} \mathrm{C}\right)$ for epifluorescence microscopy. Slides were analyzed within 2 mo of preparation. Individual protist grazers were located using UV excitation and the DAPI-induced white fluorescence of grazer nuclei and cytoplasm. The number of prey cells contained in each individual's food vacuole(s) was then enumerated using blue light excitation and the red autofluorescence of the ingested phytoplankton prey. The feeding rate reported for a single sample represents the average ingestion of 100 to 200 individuals.

Compound- and dose-dependence of feeding rates. Experiments were conducted under controlled temperature conditions $\left(15^{\circ} \mathrm{C}\right)$ by placing incubation bottles in beakers suspended in a water bath. For all experiments, grazers were allowed to acclimate to added chemicals for 15 min before addition of prey cells.

Favella sp. was fed autotrophic dinoflagellate Heterocapsa triquetra (Øresund isolate SCCAP K-481): Initial concentrations of Favella sp. and $H$. triquetra were 10 to 18 and 620 cells ml ${ }^{-1}$, respectively. Samples for microscopy were preserved 5 min after prey addition. Favella sp. feeding inhibition was studied in 4 separate experiments: 1 examining the effects of DMSP functional analogues including various algal antioxidants and osmolytes; 2 separate experiments examining the effects of various amino acids; and 1 experiment assessing dependence of feeding inhibition on proline dose.

Gyrodinium dominans was fed cryptophyte Rhodomonas salina strain \#1 (Danish Institute for Fisheries
Research strain): Initial concentrations of G. dominans and $R$. salina \#1 were 150 and 6800 cells $\mathrm{ml}^{-1}$, respectively. Samples for microscopy were preserved $2 \mathrm{~h}$ after prey addition. One experiment was conducted to examine the effects of amino acids and related compounds on feeding.

Coxliella sp. fed cryptophyte Rhodomonas salina strain \#2 (CCMP1319, aka Pyrenomonas salina). Initial concentrations of Coxliella and $R$. salina \#2 were 17 and 11600 cells $\mathrm{ml}^{-1}$, respectively. Samples for microscopy were preserved 45 min after prey addition. One experiment was conducted as for Gyrodinium dominans.

Effects of long-term exposure to chemicals. Two experiments were conducted to determine whether Favella sp. could adapt (sensu Machemer \& Teunis 1996) to inhibitory chemicals; in other words, would the feeding inhibition effect weaken or disappear after prolonged exposure? The first experiment lasted $4 \mathrm{~h}$ and the second lasted $24 \mathrm{~h}$; Favella sp. concentrations in the 2 experiments were 19 and 4 cells $\mathrm{ml}^{-1}$, respectively. Both experiments were conducted in a walk-in environmental chamber at $15^{\circ} \mathrm{C}$ with prestarved Favella sp. and Heterocapsa triquetra (at 620 cells $\mathrm{ml}^{-1}$ ) as prey. To initiate the experiments, prestarved Favella sp. from a single batch culture were divided into $500 \mathrm{ml}$ polycarbonate bottles (3 per treatment, actual volume $450 \mathrm{ml}$ ) and bottles were spiked with chemicals (225 $\mu$ l addition volume). Treatments in the first experiment were $20 \mu \mathrm{M}$ proline and an ultra-pure water control; treatments in the second experiment were $20 \mu \mathrm{M}$ serine (inhibitory), $20 \mu \mathrm{M}$ arginine (neutral), and an ultra-pure water control. These bottles contained no prey cells. After chemical addition, the $500 \mathrm{ml}$ bottles were immediately subsampled (42 ml) into $60 \mathrm{ml}$ polycarbonate bottles containing $H$. triquetra cells for a 'time zero' determination of feeding rate. A $20 \mathrm{ml}$ subsample of Favella sp. plus $H$. triquetra was taken from each $60 \mathrm{ml}$ bottle and used to completely fill a polystyrene slideflask chamber for video-taping of swimming behavior (see section 'Swimming behavior filming and analysis'); the remaining $22 \mathrm{ml}$ was allowed to incubate for $5 \mathrm{~min}$ before preservation for epifluorescence examination of food vacuoles as described above. Subsequent samples were transferred from the $500 \mathrm{ml}$, amino acid-spiked bottles to the smaller bottles for determination of feeding rate and swimming behavior at additional time points.

To determine whether exposure to amino acids increased ciliate mortality, we took additional samples $(20 \mathrm{ml})$ from the $500 \mathrm{ml}$ bottles at 0,12 and $24 \mathrm{~h}$ during the second experiment. These were preserved in acid Lugol's solution (final concentration 10\%) for determination of ciliate abundance. Samples were settled and ciliates counted using inverted microscopy. Growth 
rates in each bottle were determined from the slope of ln-transformed abundance vs. time relationships. A further set of samples (each $18 \mathrm{ml}$ ) was taken at all time points for determination of DFAA concentration in both spiked and control bottles.

Feeding history experiment. We tested whether feeding history (starved vs. well fed) affected the feeding response to added proline, one of the most inhibitory amino acids. Additionally, some starved Favella sp. were exposed to filtrate from the dinoflagellate prey culture to determine whether dissolved cues from prey modulated the inhibitory effect of proline. The experiment was performed as above, except that Favella sp. in some treatments were not prestarved. All Favella sp. were sieved and resuspended in fresh medium $22 \mathrm{~h}$ before the experiment. However, Heterocapsa triquetra prey cells were immediately added back to one portion of the stock culture (to 620 cells $\mathrm{ml}^{-1}$ ) so that these Favella sp. were well fed before the experiment, while another portion of the stock culture was prestarved. Prey cell density in the well-fed Favella sp. culture was estimated and additional prey were added (to 620 cells ml$^{-1}$ ) $5 \mathrm{~h}$ before the experiment. The prestarved portion was further divided into a portion that was left untreated and a second portion that was combined with filtrate from $H$. triquetra culture $22 \mathrm{~h}$ and $5 \mathrm{~h}$ before the experiment. Filtrate was prepared using a polycarbonate filter $(0.8 \mu \mathrm{m}$ pore size), and this was added in the same proportions (22 h: 12 to $400 \mathrm{ml} ; 5 \mathrm{~h}: 7$ to $412 \mathrm{ml}$ ) as $H$. triquetra culture to Favella sp. stock culture in the well-fed treatment.

Feeding rates with and without added $20 \mu \mathrm{M}$ proline were measured in 3 treatments: well fed, starved, and starved plus prey culture filtrate. Feeding rates were measured as uptake of fluorescently labeled algae (FLA) over 10 min. FLA were prepared from $H$. triquetra the day before the feeding experiment by staining them with 5-([4,6-dichlorotriazin-2-yl]amino)fluorescein hydrochloride (DTAF) at $65^{\circ} \mathrm{C}$ according to Rublee \& Gallegos (1989). Prey cells were added to all treatments as a 15:85 mixture of FLA : unstained $H$. triquetra. For the well-fed culture, the unstained fraction included the prey cells that remained in the bottle from the previous (22 and $5 \mathrm{~h}$ ) feedings. For all treatments, total ingestion was calculated by scaling FLA uptake by the FLA:unstained Heterocapsa triquetra proportion. Total FLA + unstained $H$. triquetra concentration was 620 cells ml $^{-1}$ in all treatments; Favella sp. density was 16 cells $\mathrm{ml}^{-1}$.

Recovery experiment. We determined the time course and extent of Favella sp. feeding rate recovery from exposure to proline. Experiments were conducted at $15^{\circ} \mathrm{C}$ in dim light in a walk-in environmental chamber. Three treatments were used, each in triplicate: control (no chemical exposure, followed by rinsing in clean ciliate medium), proline recovery (exposure to $20 \mu \mathrm{M}$ proline followed by rinsing in clean medium), continuous proline exposure (exposure to $20 \mu \mathrm{M}$ proline followed by rinsing in $20 \mu \mathrm{M}$ proline-enriched medium). Rinsing and resuspension of cells in each bottle ensured that handling effects were the same for all treatments. Prestarved Favella sp. at $28 \mathrm{cells} \mathrm{ml}^{-1}$ were suspended in $200 \mathrm{ml}$ of ciliate medium that was then spiked with the appropriate chemical (100 $\mu \mathrm{l}$ Nanopure water for controls, $100 \mu$ proline solution for proline-exposed treatments). After $10 \mathrm{~min}$ exposure to chemicals, the contents of each bottle were poured through a $20 \mu \mathrm{m}$ mesh sieve to retain Favella sp. cells. These were rinsed in the sieve with 2 approximately $100 \mathrm{ml}$ volumes of the appropriate solution (clean ciliate medium for control and recovery treatments, $20 \mu \mathrm{M}$ proline-enriched medium for continuous exposure treatment), Favella sp. cells were then resuspended (to $200 \mathrm{ml}$ ) in the same solutions and immediately subsampled $(30 \mathrm{ml})$ for the first feeding rate determination. Feeding rates in the subsamples were measured on Heterocapsa triquetra at 620 cells ml ${ }^{-1}$ over a 5 min incubation, as described in 'Feeding rate measurements (general approach)' (above). Additional feeding rate measurements were made at time intervals up to $1 \mathrm{~h}$ after rinsing and resuspension.

Swimming behavior filming and analysis. We videotaped and analyzed Favella sp. swimming behavior in conjunction with 4 feeding experiments, as well as in 6 trials without feeding. Although initial tests used a $15^{\circ} \mathrm{C}$ water bath to maintain temperatures, most experiments were conducted in a walk-in incubator. Cultures were dispensed into $20 \mathrm{ml}$ polystyrene slideflask chambers, and amino acids were added to final concentration of 2 to $200 \mu \mathrm{M}$. Controls received equivalent volumes of Nanopure water. Swimming was filmed with a dissecting microscope (Olympus CO11 with darkfield adapter) for 2 to 3 min intervals at 4 to 6 time points. Light levels were reduced to a minimum, and the focal plane was set near the middle of the flask to avoid tracks that might be influenced by chamber walls. Video (30 frames $\mathrm{s}^{-1}$ ) was generated with a Sony B/W camera and recorded by VCR. Videos were digitized with a Videum 1000 frame capture board (Winnov) and compressed using Intel Video R3.2 format.

LabTrack 2.0 (Bioras) was used to track cell motion. Typical parameter settings were as follows: threshold : 50 to 100 , depending on lighting; min track length: 30 frames; search radius: 10 pixels; min target size: 4 pixels; max target size: 50 pixels; min velocity: $1.00 \mathrm{pixel} /$ frame. To avoid bias by track fragments, only tracks greater than 30 frames (1 s) in duration were retained and analyzed. Pixels were converted to microns from slide micrometer measurements and 
saved as Excel-readable output files. Output data for each cell track included time and position for each frame, and velocity $(V)$ acceleration $(A)$, and angle averaged successively (i.e. a running average) over 6 frames. Over 10 experiments, video acquisition ranged from 60 to 385 tracks per tape, each track with 30 to 600 frames, for a total of 2700 to 5000 tracks in 250 to $500 \mathrm{~min}$ of video per experiment.

Bulk track statistics were calculated from output files with a PERL script. For each track, we calculated the average velocity and $1 \mathrm{~s}$ averaged net-gross-displacement ratio (NGDR), a measure of turning rate. In addition, tracks were analyzed for helical vs. straight swimming patterns using wavelet analysis, which extracts local-frequency information from a time series signal by decomposing it into time-frequency space using periodic functions, and thus determines how the signal changes over time. The $y$ component of the velocity of each track was concatenated into a series of sequential frame numbers and analyzed with a weighted wavelet Z-transform using the program WinWWZ (www.aavso. org/data/software/winwwz.shtml). This analysis produces a running series of local frequency, period, and amplitude averaged around a moving window for each frame. Parameters were as follows: time step $=10$, low freq $=0.002$, high freq $=0.05$, freq step $=0.002$, constant $=0.05$, and bin width $=3$. By inspection, an arbitrary threshold value of the product of frequency and amplitude could be used to determine helical versus straight swimming.

Statistical analyses. Experiments investigating compound- and dose-dependence of feeding rates in Favella sp., Gyrodinium dominans and Coxliella sp. were analyzed using ANOVA followed by Tukey's HSD post-hoc test for multiple comparisons. Data from one of the Favella sp. experiments examining the effects of various amino acids did not meet the assumption of equality of variances despite the use of various data transformation methods. Therefore post-hoc multiple comparisons for this experiment used the GamesHowell test. Data from the feeding history experiment were analyzed with the paired samples $t$-test, while long-term exposure experiments were analyzed with repeated measures ANOVA. All statistical analyses were performed with SPSS v. 14.0 software.

\section{RESULTS}

\section{Compound- and dose-dependence of feeding rates}

We found no effect of the algal antioxidants ascorbic acid, glutathione, dimethylsulfoxide, or acrylate on Favella sp. feeding rate (Table 1). Similarly, the algal osmolytes mannitol and betaine did not affect feeding rates. The osmolytes DMSP and proline, an amino/ imino acid, reduced feeding to 63 and $23 \%$ of the control rate, respectively (Table 1).

The finding that $20 \mu \mathrm{M}$ proline was strongly inhibitory led us to investigate other amino acids. These showed a wide range of effects (Fig. 1A). No amino acid was stimulatory (i.e. none promoted a feeding rate significantly higher than the control), and many were inhibitory. Rates in treatments that significantly reduced feeding ranged from 64 to $5 \%$ of the control, with the lowest rates caused by addition of valine and cysteine. Other particularly inhibitory amino acids were proline, alanine, and serine, all of which reduced feeding to $<20 \%$ of the control rate (Fig. 1A). We tested the effects of 2 other low molecular weight compounds as well: sodium pyruvate and ammonium chloride. Neither affected Favella sp. feeding rates at a concentration of $20 \mu \mathrm{M}$ (data not shown).

The strength of the inhibition was inversely proportional to the length of the amino acid side chain, with small side chain amino acids the most inhibitory (Fig. 1B). Glycine, with no side chain, showed only a weak effect. Inhibition was not clearly related to side chain polarity or charge. For example, among the strongly inhibitory compounds, proline, alanine, and valine are non-polar, while serine and cysteine are polar. Among the weakly or non-inhibitory compounds, lysine, arginine and histidine are positively charged, while aspartic and glutamic acids are negatively charged, and trypotophan and isoleucine are neutral.

The dose-response experiment showed that feeding inhibition in Favella sp. was dependent on proline concentration (Fig. 2). The lowest tested concentration with an inhibitory effect was $200 \mathrm{nM}$. With increasing

Table 1. Favella sp. fed Heterocapsa triquetra. Feeding inhibition (feeding rate as \% of control) of the tintinnid in the presence of $20 \mu \mathrm{M}$ antioxidants and organic osmolytes. Values are averages $(n=4)$ with 1 SD in parentheses. Rates that are statistically significantly different from controls are in bold (DMSP: $p=0.057$; proline: $p<0.001$ ). Control feeding rate averaged $0.41( \pm 0.10)$ cells grazer ${ }^{-1} \mathrm{~min}^{-1}$

\begin{tabular}{|lc|}
\hline $\begin{array}{l}\text { Functional class } \\
\text { Compound }\end{array}$ & $\begin{array}{c}\text { Feeding rate } \\
\text { (\% of control) }\end{array}$ \\
\hline Antioxidants & \\
Glutathione & $92(10)$ \\
Ascorbate & $102(11)$ \\
DMSO & $112(22)$ \\
Acrylate & $117(17)$ \\
Osmolytes & \\
Mannitol & $104(19)$ \\
Betaine & $88(14)$ \\
DMSP & $\mathbf{6 3}(7)$ \\
Proline & $\mathbf{2 3}(5)$ \\
\hline
\end{tabular}



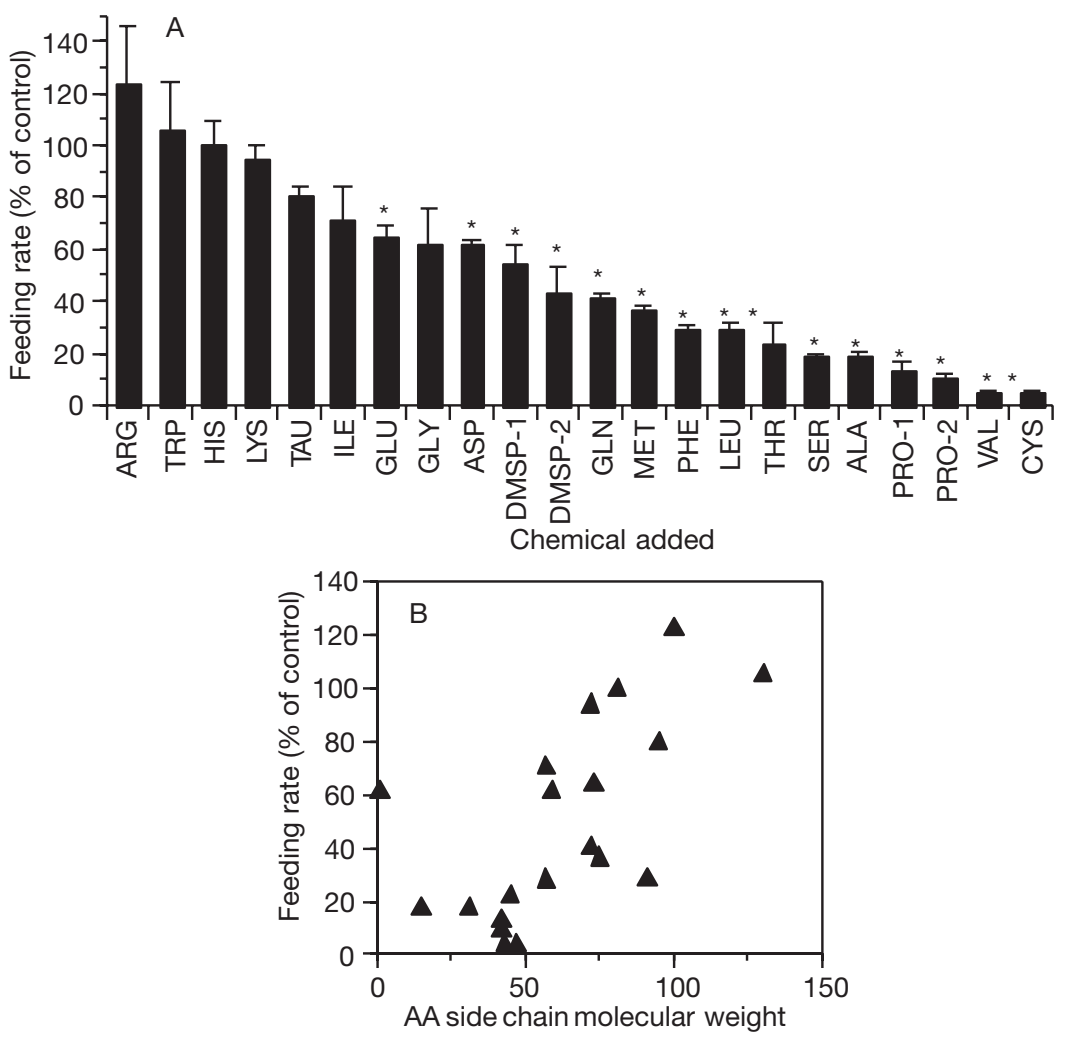

Fig. 1. Favella sp. feeding on Heterocapsa triquetra. (A) Feeding rates of the ciliate (as \% of control rates, mean $\pm 1 \mathrm{SD}, \mathrm{n}=4$ ) in the presence of $20 \mu \mathrm{M}$ concentrations of 19 amino acids, DMSP and betaine. Combined results of 2 experiments conducted within 2 mo of each other (DMSP and proline data shown for both experiments). Data are arranged from highest to lowest average rates; ${ }^{*}$ rates that are statistically significantly different from controls $(\mathrm{p}<0.05)$. Control feeding rates averaged $0.99 \pm 0.10$ and $0.90 \pm 0.02$ cells grazer ${ }^{-1} \mathrm{~min}^{-1}$ for the first and second experiments, respectively. (B) Favella sp. feeding rates from (A) as a function of amino acid (AA) side chain molecular weight. arg: arginine; trp: tryptophan; his: histidine; lys: lysine; tau: taurine; ile: isoleucine; glu: glutamic acid; gly: glycine; asp: aspartic acid; DMSP: dimethylsulfoniopropionate; gln: glutamine; met: methionine; phe: phenylalanine; leu: leucine; thr: threonine; ser: serine; ala: alanine; pro: proline; val: valine; cys: cysteine feeding inhibition) was not seen over $4 \mathrm{~h}$ exposure, with rates remaining consistent at or below $40 \%$ relative to the control (Fig. 3A,B). The slight overall increase in all feeding rates during the $4 \mathrm{~h}$ time course is consistent with the documented diel cycle of Favella sp. (Jakobsen \& Strom 2004). In the second experiment, longer exposure to amino acids led to partial adaptation but not to complete recovery. Feeding in the presence of added serine increased from 48 to $84 \%$ of control rates over $12 \mathrm{~h}$, after which both absolute and relative rates decreased (Fig. 3C,D). Arginine had no effect on feeding at any time point. DFAA analyses showed that serine and arginine concentrations changed little during the incubations. Serine decreased from 19.10 to $17.60 \mu \mathrm{M}$ and arginine from 20.45 to $19.67 \mu \mathrm{M}$ over the $24 \mathrm{~h}$ period. Total DFAA concentration in the control bottles averaged $0.35 \mu \mathrm{M}$ initially and $0.19 \mu \mathrm{m}$ after $24 \mathrm{~h}$ incubation.

These experiments also demonstrate the lack of amino acid toxicity. Longterm exposure to $20 \mu \mathrm{M}$ serine and arginine had no effect on $24 \mathrm{~h}$ growth rates of Favella sp. (1-way ANOVA, p = 0.97). Rates were variable but low and positive on average, indicating little or no mortality in the bottles. Average growth rates $( \pm 1 \mathrm{SD})$ were $0.22 \mathrm{~d}^{-1}( \pm 0.26)$ for the control treatment, $0.21 \mathrm{~d}^{-1}( \pm 0.41)$ for the serine treatment, and $0.16 \mathrm{~d}^{-1}( \pm 0.41)$ for the arginine treatment.

Feeding inhibition was not dependent on feeding history. Favella sp. ingestion proline concentration, feeding rate decreased from $63 \%$ of the control rate at $200 \mathrm{nM}$ to $10 \%$ at $20 \mu \mathrm{M}$.

\section{Long-term exposure and feeding history effects}

The 2 long-term exposure experiments demonstrate the rapidity of the inhibitory effect, which occurred in $<5$ min following exposure to the active amino acids. During both experiments we initiated a 5 min feeding assay immediately following addition of $20 \mu \mathrm{M}$ amino acids. Over the course of the $5 \mathrm{~min}$ assay, proline reduced feeding to $20 \%$ of control levels in the first experiment, while serine reduced feeding to $48 \%$ of control levels in the second experiment (Fig. 3B,D). Adaptation to the added proline (i.e. recovery from

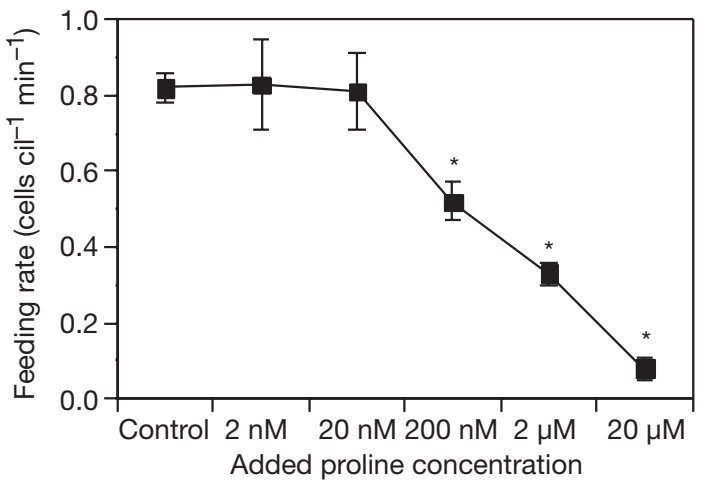

Fig. 2. Favella sp. feeding on Heterocapsa triquetra. Effect of increasing proline dose on ciliate (cil) ingestion of $H$. triquetra (mean $\pm 1 \mathrm{SD}, \mathrm{n}=4$ ). ${ }^{*}$ Rates that are statistically significantly different from controls $(p<0.001)$ 

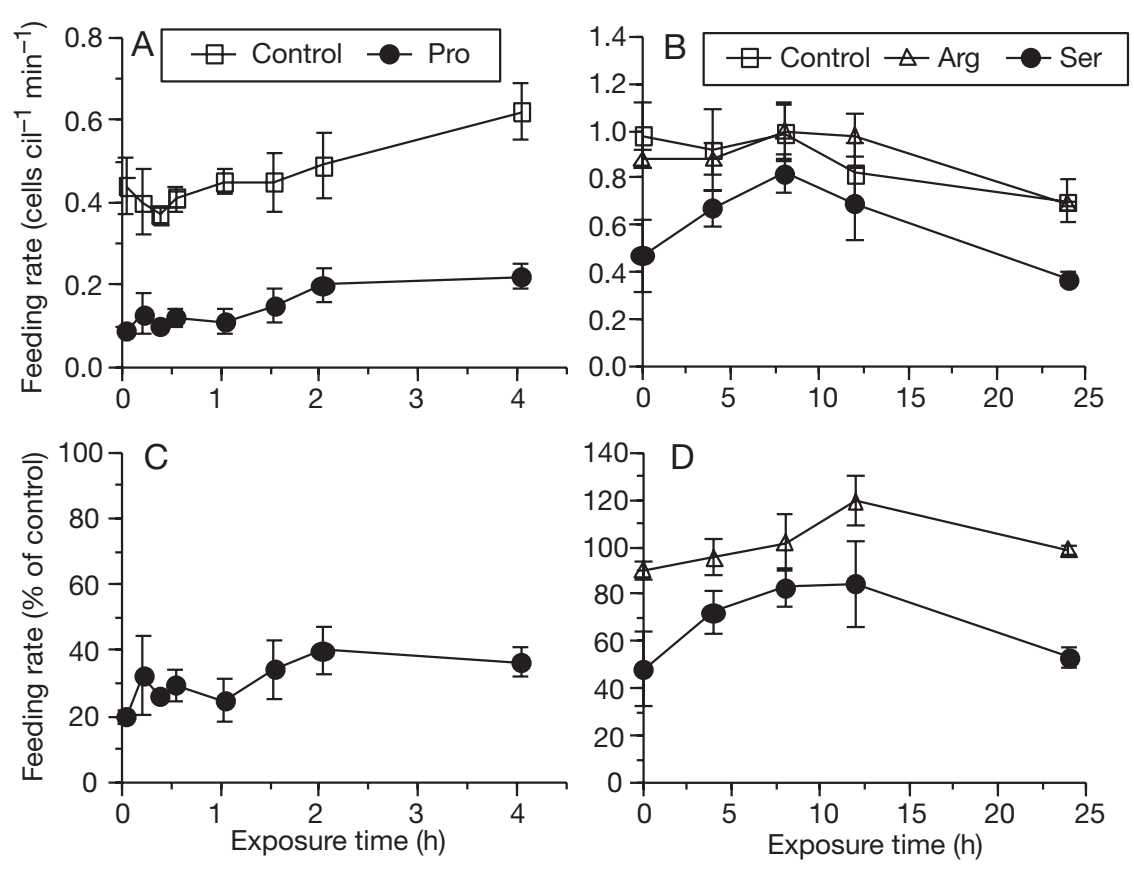

Fig. 3. Favella sp. Feeding rates of the ciliate (cil) (mean $\pm 1 \mathrm{SD}, \mathrm{n}=3$ ) during 2 long-term amino acid exposure experiments. $(\mathrm{A}, \mathrm{B})$ absolute feeding rates; $(\mathrm{C}, \mathrm{D})$ rates in amino acid treatments as \% of control rates. $(\mathrm{A}, \mathrm{C}) \mathrm{A}$ $4 \mathrm{~h}$ experiment with proline (pro) and control treatments; $(\mathrm{B}, \mathrm{D}) 24 \mathrm{~h}$ experiment with serine (ser), arginine (arg), and control treatments. Addition of proline or serine significantly reduced

feeding rates (ANOVA, $\mathrm{p}<0.01$ )

rate in the presence of $20 \mu \mathrm{M}$ proline was very low (0.03 to 0.05 cells ciliate $\mathrm{min}^{-1}$ ) regardless of whether the ciliates were previously fed, starved, or starved in the presence of filtrate from the Heterocapsa triquetra prey culture (Fig. 4). Control (i.e. no proline) feeding rates were lower in the well-fed culture than in the 2 prestarved treatments (0.26 vs. 0.41 cells ciliate ${ }^{-1} \mathrm{~min}^{-1}$, respectively). Thus, the proline inhibitory effects varied when normalized to the appropriate controls, with feeding rates $18 \%$ of con-

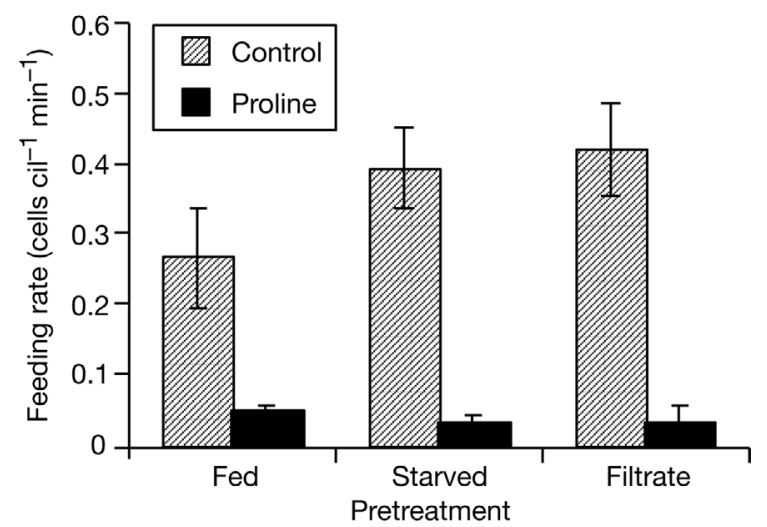

Fig. 4. Favella sp. Feeding rates of the ciliate (cil) (mean \pm $1 \mathrm{SD}, \mathrm{n}=4$ ) in control and $20 \mu \mathrm{M}$ proline treatments after preincubation in 3 different feeding conditions: fed (Heterocapsa triquetra), starved, and starved in the presence of filtrate from $H$. triquetra culture. Rates in all proline treatments were statistically significantly lower than corresponding control rates $(\mathrm{p}<0.01)$ trol rates in the well-fed treatment, and 7 to $8 \%$ in the prestarved treatments.

\section{Recovery from amino acid exposure}

Partial recovery of Favella sp. feeding rates from exposure to proline was very rapid. Observations made immediately after rinsing and resuspension showed that feeding in the proline recovery treatment averaged $48 \%$

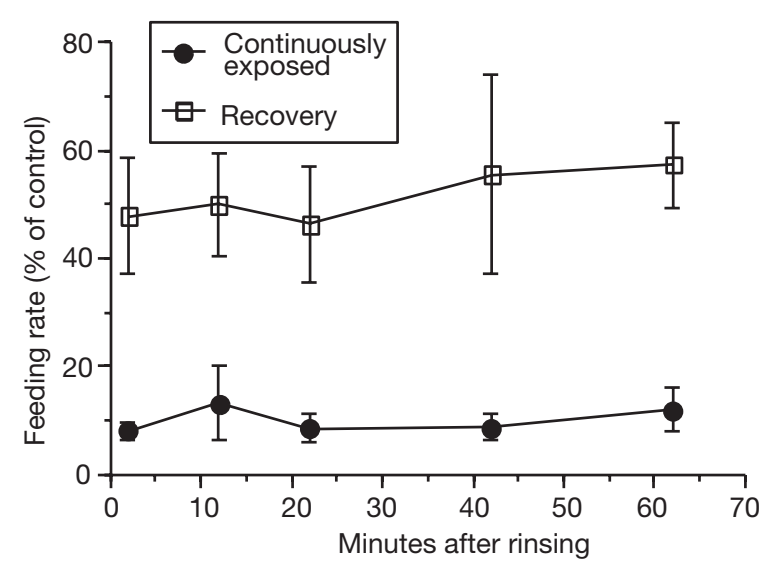

Fig. 5. Favella sp. Feeding rates of the ciliate (as \% of control, mean $\pm 1 \mathrm{SD}, \mathrm{n}=3$ ) during the recovery experiment. Rates are shown for proline recovery and continuously proline-exposed treatments. Control feeding rates averaged $0.24 \pm 0.05$ for the first time point and $0.43 \pm 0.09$ cells grazer ${ }^{-1} \mathrm{~min}^{-1}$ for all other time points 


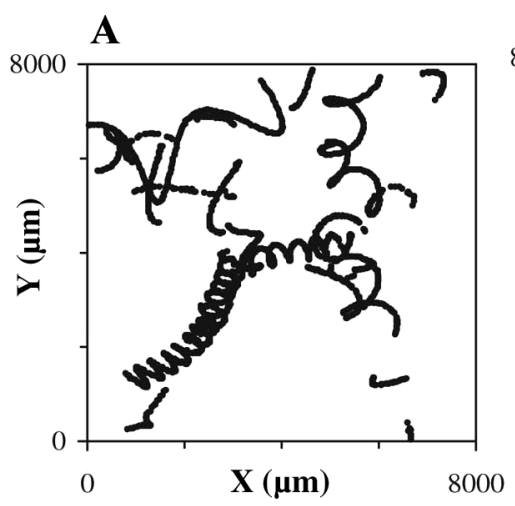

B

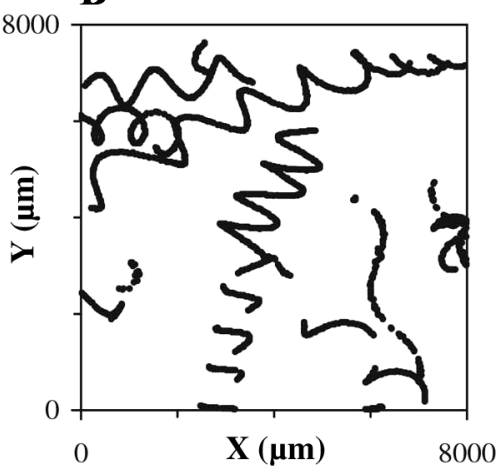

C

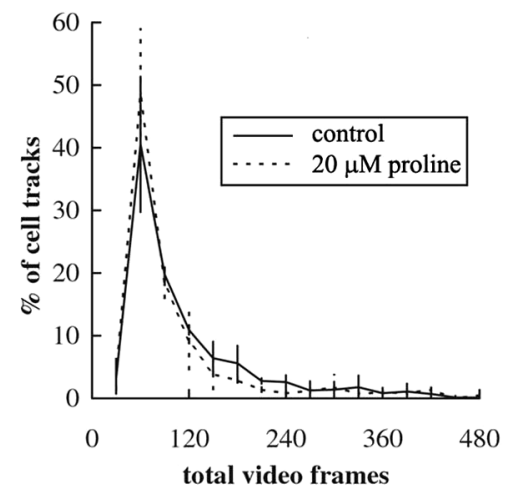

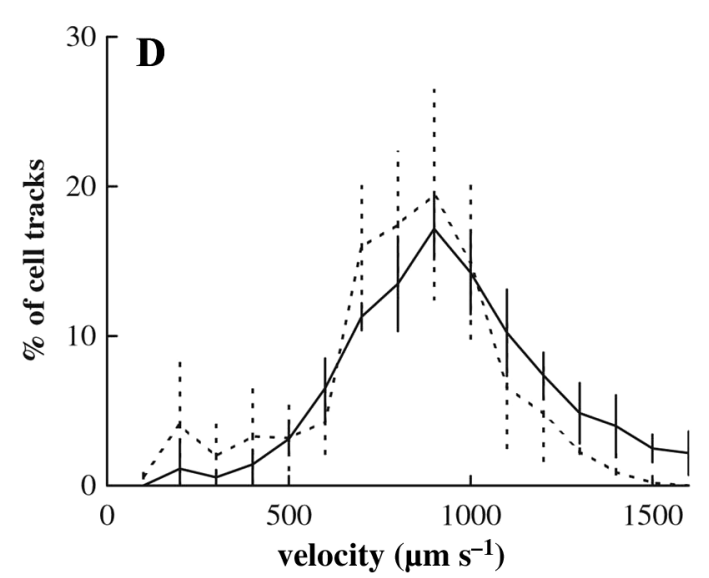

${ }^{40}[\mathbf{E}$
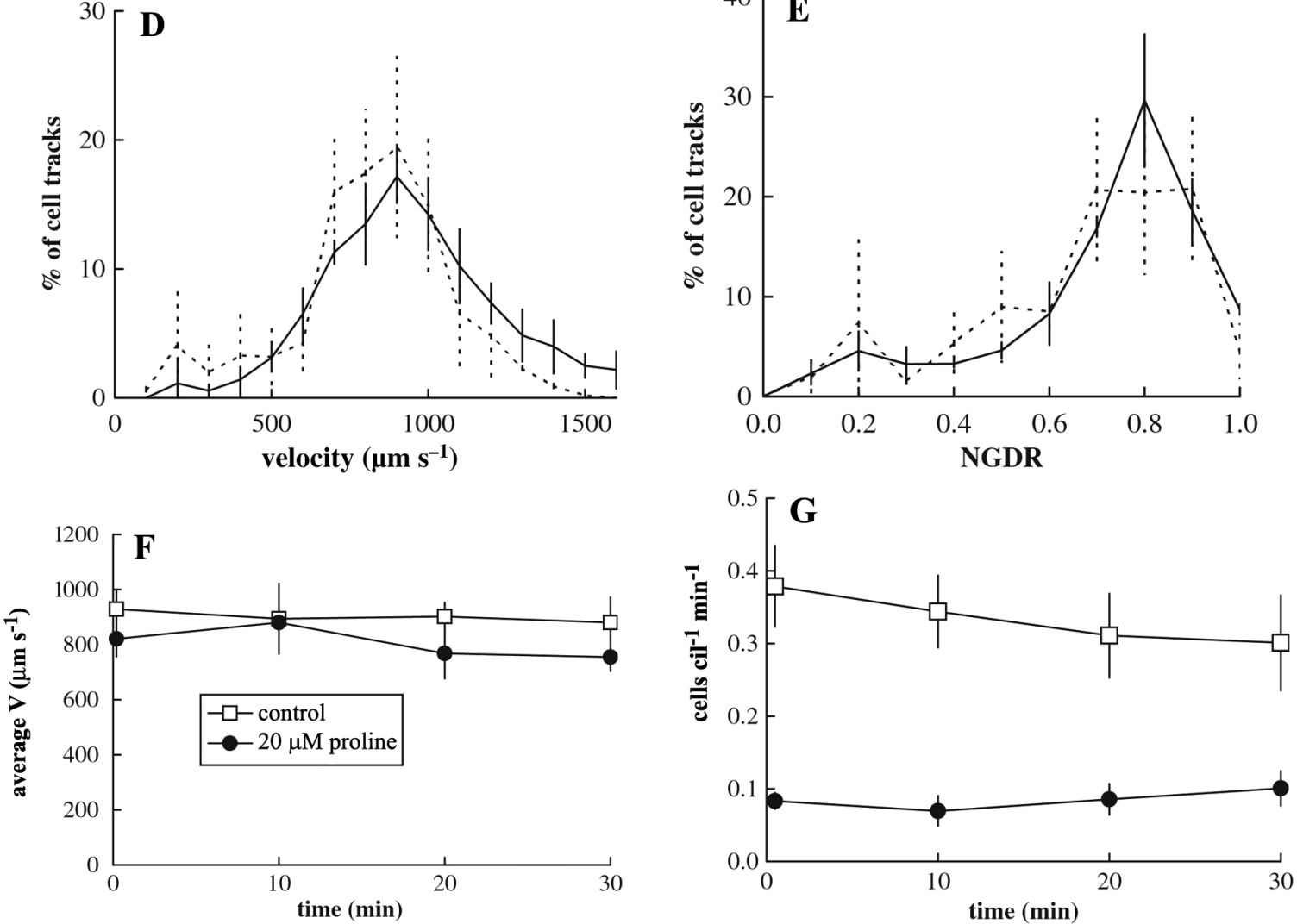

Fig. 6. Favella sp. Swimming behavior analysis. Examples of helical swimming (selected tracks) in (A) control at 20 min and (B) $20 \mathrm{\mu M}$ proline at $30 \mathrm{~min}$. (C) Frames per track showing that most tracks were 2 to $4 \mathrm{~s}$ in duration $\left(30 \mathrm{frames} \mathrm{s}^{-1}\right)$, with a small number of tracks up to $15 \mathrm{~s}$. Exposure to proline $(20 \mu \mathrm{M}$ for $20 \mathrm{~min}$ ) had no effect on distributions of (D) velocity (binned into $100 \mu \mathrm{m}$ $\mathrm{s}^{-1}$ increments) or (E) NGDR (net-gross-displacement ratio, binned into 0.1 increments). Similarly, $20 \mu \mathrm{M}$ proline did not significantly change $(F)$ average velocity $(V)$ or NGDR (not shown) over $30 \mathrm{~min}$. (G) Feeding inhibition was, in contrast, immediate and profound. Data in $\mathrm{C}$ to $\mathrm{G}$ are mean $\pm 1 \mathrm{SD}(\mathrm{n}=3)$. Cil: ciliate

of control rates (Fig. 5). In contrast, feeding in the continuously proline-exposed treatment averaged only $8 \%$ of control rates. No additional recovery was observed within the $1 \mathrm{~h}$ time course of our experiment. Rates remained unchanged, with averages ranging from 46 to $57 \%$ of control rates in the recovery treatment, and 8 to $13 \%$ in the continuously exposed treatment.

\section{Effects of amino acids on swimming behavior}

In control flasks, ciliates swam in a variety of helices (Fig. 6A), which did not change dramatically when amino acids were added (Fig. 6B). Most tracks were 2 to $4 \mathrm{~s}$ in duration, although a small number were much longer (Fig. 6C). Although individual cells varied 

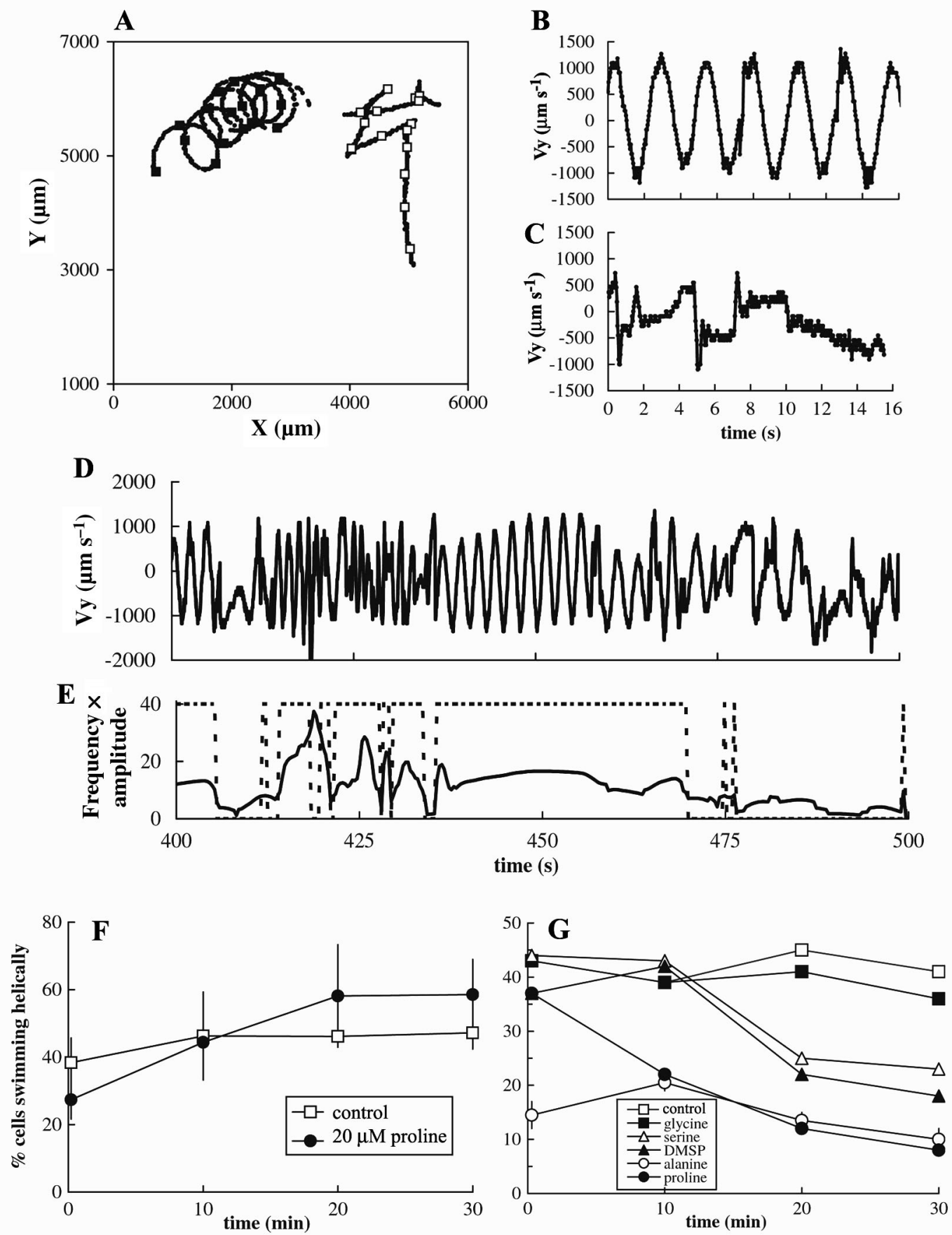

Fig. 7. Favella sp. Use of wavelet analysis to estimate fraction of cells exhibiting helical swimming. (A) Selected tracks exhibiting helical (left) or start-stop (right) behavior, with symbols denoting $1 \mathrm{~s}$ intervals. (B,C) $V_{Y}$ ( $y$ component of velocity $V$ ) vs. time for (B) helical and (C) start-stop swimming. (D,E) Example of concatenated track $V y$ and wavelet analysis, showing threshold detection of helices (dotted line in E). ( $F, G)$ Change in percent helical swimming over time. (F) Experiment in which feeding was reduced by presence of $20 \mu \mathrm{M}$ proline (mean $\pm 1 \mathrm{SD}, \mathrm{n}=3$ ). Fraction of cells swimming helically increased over 20 min, but not significantly. (G) Experiment testing behavior in presence of $20 \mu \mathrm{M}$ amino acids or DMSP, in which helical swimming was reduced by some amino acids. $\mathrm{n}=1$; error bars on alanine denote pseudoreplicate variability of different track populations

considerably, the distributions of $V$ and NGDR were unimodal and not significantly changed by amino acid additions (Fig. 6D,E). Average swimming speed ranged from 600 to $1200 \mu \mathrm{m} \mathrm{s}^{-1}$, with an average
NGDR of 0.6 to 0.8 . Neither $V$ (Fig. 6F) nor NGDR (data not shown) changed over time or with amino acid addition, in sharp contrast to feeding depression, which was consistently immediate (Fig. 6G). 
Closer examination of individual swimming tracks showed that a fraction of cells did not swim helically, but in 'start-stop' movements that resulted in zig-zag patterns (Fig. 7A). When the $y$ component of velocity $(V y)$ was plotted against time, these cells could be distinguished from those swimming helically (Fig. 7B,C). We concatenated tracks of all cells and used wavelet analysis to determine the fraction of the time cells were swimming helically (Fig. 7D,E). Although we did not see consistent changes in the degree of helical swimming between experiments, there appeared to be subtle trends (Fig. 7F) that occurred over 10 to $30 \mathrm{~min}$. In at least one instance, the fraction of cells exhibiting helical swimming decreased in response to amino acids (alanine, proline, serine) that strongly inhibited feeding (Fig. 7G). However, these results were not consistent among experiments. Helical period and amplitude did not vary significantly among treatments or over time regardless of experiment (data not shown).

\section{Amino acid inhibition of other protist grazers}

Experiments with Coxliella sp. and Gyrodinium dominans demonstrated that the inhibitory effect of amino acids and related compounds on other heterotrophic protists is variable. The heterotrophic dinoflagellate G. dominans showed no response to added amino acids, including serine, histidine, cysteine, arginine, lysine, valine, proline, glutamine, and glutamic acid. Nor did G. dominans respond to DMSP or betaine (1-way ANOVA, p = 0.93; data not shown). Feeding rates averaged 0.4 cells grazer ${ }^{-1} \mathrm{~h}^{-1}$ across all treatments. In contrast, feeding by the tintinnid ciliate Coxliella sp. was moderately inhibited by some tested compounds (Fig. 8). Addition of $20 \mu \mathrm{M}$ betaine and DMSP reduced feeding to 45 and $56 \%$ of control rates, respectively. The data also suggest that proline was an effective inhibitor (to $60 \%$ of control rates, $\mathrm{p}=$ 0.082, Tukey HSD post-hoc comparison). However, Coxliella was not affected by glutamine or valine, amino acids that moderately or strongly inhibited Favella sp. (Fig. 1A). Unfortunately Coxliella was lost from culture before additional compounds could be tested.

\section{DISCUSSION}

\section{Amino acids as chemical signals}

We found that numerous amino acids inhibited feeding by the tintinnid ciliate Favella sp., a geographically widespread coastal genus. The most inhibitory amino

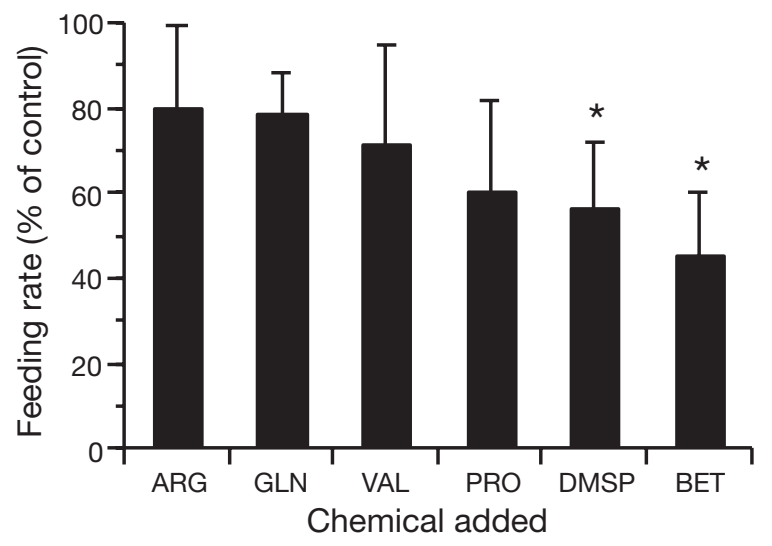

Fig. 8. Coxliella sp. feeding on Rhodomonas salina. Feeding rates of the ciliate on $R$. salina strain \#2 (as \% of control rates, mean $\pm 1 \mathrm{SD}, \mathrm{n}=4$ ) in the presence of $20 \mu \mathrm{M}$ concentrations of 4 amino acids, DMSP and betaine (BET). * indicates rates significantly different from controls $(\mathrm{p}<0.05)$. Control feeding rates averaged $1.5 \pm 0.3$ cells grazer ${ }^{-1} \mathrm{~h}^{-1}$. Abbreviations as in Fig. 1

acids - valine, cysteine, proline, alanine, and serine reduced feeding to $<20 \%$ of the control rate at $20 \mu \mathrm{M}$ concentration. Several lines of evidence indicate that these amino acids are signaling compounds for Favella sp. (1) Long-term (24 to $28 \mathrm{~h}$ ) exposure to inhibitory amino acids had no effect on growth or mortality of Favella sp., demonstrating that the compounds are not toxic. (2) Favella sp. responded to proline, one of the more inhibitory DFAAs, at concentrations as low as 200 nM. (3) Removal of amino acids caused immediate partial reversal of inhibition. (4) We observed a clear effect of amino acid side chain size on feeding inhibition, suggesting a specific interaction with a cell surface receptor. DFAAs are released both by phytoplankton (prey for Favella sp.) and during grazing by copepods and other zooplankton (potential predators of Favella sp.), so the potential 'information content' of these molecules is high. Once released, DFAAs have a short lifetime in seawater, as they are preferred substrates for bacterial uptake and growth. Thus, background concentrations in seawater are low and pulses short-lived (see next section). This is consistent with a signaling function in that the Favella sp. feeding response would not be triggered by environmental 'background' DFAA levels, but would be responsive to realistic enhancements associated with localized release of the compounds.

It is well known that free amino acids are signaling compounds for a broad range of aquatic organisms. Extensive research on crustaceans (amphipods, copepods, crabs, lobsters) and fishes has shown that DFAAs can be attractants and feeding stimulants (e.g. Poulet \& Ouellet 1982, Carr et al. 1996, Ide et al. 2006). DFAAs 
are released from decomposing animal tissue so these responses are adaptive for organisms that search for and consume detritus. Feeding stimulation, neurological responsiveness, and behavioral attraction by DFAAs has also been reported for echinoderms (Valentincic 1985), a nudibranch (Murphy \& Hadfield 1997), a mud snail (Zimmer et al. 1999) and a planarian (Miyamoto \& Shimozawa 1985). Some larval invertebrates use free amino acids as cues for settlement and metamorphosis, including the oyster Crassostrea virginica and the queen conch Strombus gigas (Zimmer-Faust \& Tamburri 1994, Boettcher \& Targett 1998). Among aquatic microbes, amino acids are attractants for abalone sperm (Riffell et al. 2002), numerous bacteria (Miller et al. 2004 and references therein) and protists including the crypotophyte Chroomonas sp., the heterotrophic dinoflagellate Gymnodinium fungiforme, the nanoflagellate Pseudobodo tremulans and the ciliate Tetrahymena (Levandowsky et al. 1984, Spero 1985, Sibbald et al. 1987, Lee et al. 1999).

These studies, and many others, demonstrate that DFAAs are generally attractants and stimulants for aquatic organisms, over effective concentrations ranging from 10 s of nanomolar to millimolar. This contrasts sharply with our results showing a range of DFAAs to be inhibitors of ciliate feeding. To our knowledge, only a few prior studies have reported inhibitory or deterrent effects of amino acids. Ferner \& Jumars (1999) found spionid polychaete feeding was depressed by millimolar concentrations of taruine, threonine and valine; while Hauser et al. (1975) found that several amino acids generated a negative preyseeking response in the saprophytic dinoflagellate Crypthecodinium cohnii.

\section{Could amino acids inhibit grazing in natural waters?}

Total DFAA concentrations in the marine euphotic zone can be as high as those eliciting a response from Favella sp. in our dose-response experiment. The threshold concentration for feeding inhibition was $200 \mathrm{nM}$ proline. While DFAA levels in oligotrophic waters can be $<10 \mathrm{nM}$ (e.g.

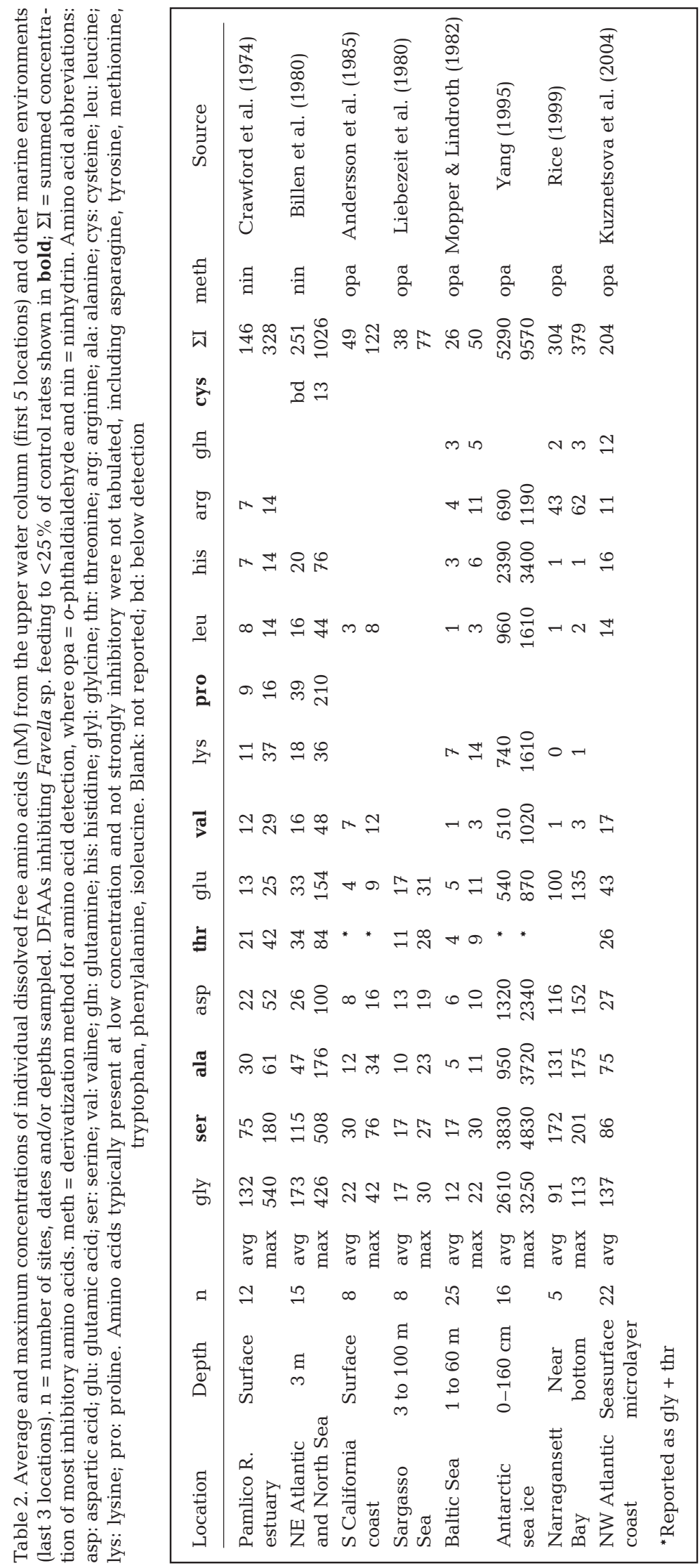


the Sargasso Sea, Hoch \& Kirchman 1995), concentrations in coastal waters typically range from 10 s to 100 s of nanomoles (Table 2). In blooms or at discontinuities, concentrations can be orders of magnitude higher. For example, Sellner \& Nealley (1997) found DFAA levels of $4.2 \mu \mathrm{M}$ in a Chesapeake Bay dinoflagellate bloom. Concentrations ranged up to $4.5 \mu \mathrm{M}$ in a copepod-rich layer of the Celtic Sea (Poulet et al. 1991), 3.6 $\mu \mathrm{M}$ in the Delaware Estuary (Hoch \& Kirchman 1995), and $27.2 \mu \mathrm{M}$ in Adriatic Sea aggregates (Simon et al. 2002).

Fewer data are available on the composition of this amino acid pool. However, serine and alanine, 2 of the most inhibitory DFAAs for Favella sp., are often major constituents (Table 2). Other amino acids that are often abundant include glycine, glutamic and aspartic acids, lysine, and ornithine. Given typical coastal concentrations of 10 s to 100 s of nanomoles for total DFAA, environmental concentrations of inhibitory amino acids would generally be too low to elicit a response from Favella sp.. On occasions, however, combined concentrations of the most inhibitory DFAAs ( $\Sigma \mathrm{I}$, Table 2) reach levels sufficient to inhibit feeding, perhaps especially in layers, patches, and microzones in the sea.

An important side note is that most measurements of marine DFAA composition have been made using $o$ phthaldialdehyde (OPA) to create fluorescent amino acid derivatives that are quantified after high-performance liquid chromatographic separation (Lindroth \& Mopper 1979). OPA reacts weakly and unstably with cysteine and proline (Birwé \& Hesse 1991, Jørgensen \& Jensen 1997), so these strongly inhibitory amino acids cannot be quantified using the OPA-HPLC method. Very little information is available on the concentrations of dissolved free cysteine and proline in marine environments.

Sources and composition of released DFAA in the marine plankton are difficult to determine due to simultaneous uptake by bacteria and protists. Direct release (exudation) by phytoplankton can be a significant source to the DFAA pool, as phytoplankton can contain substantial quantities of free amino acids (Marsot et al. 1991, Granum et al. 2002). Proline is an osmoregulator in some phytoplankton species and, as such, is present at high intracellular concentrations (Kirst 1989). Intracellular proline concentrations can increase even more in response to osmotic or oxidative stress, such as that imposed by heavy metals (Sharma $\&$ Dietz 2006). In these species, a concentrated pool of free amino acids is available for release in response to activation signals, cell disruption, and other processes. Marine bacteria and ciliates also use amino acids for osmoregulation, particularly proline, glycine, alanine, and glutamic acid (Kaneshiro et al. 1969, Csonka \& Hanson 1991, Cronkite et al. 1993). In addition to exudation, release of DFAA has been associated with grazing by copepods and protists (Andersson et al. 1985, Nagata \& Kirchman 1991, Rosenstock \& Simon 2001). Extrapolating from arguments made for total DOC release, protist grazing is likely to be a major pathway for DFAA production under non-bloom conditions when cells are turning over at high rates (Strom et al. 1997).

\section{How do amino acids act?}

Studies on model ciliates such as Paramecium, Tetrahymena, and Euplotes have revealed a range of swimming responses to both attractant and repellent dissolved cues (Van Houten 1978). Intensive study has revealed the physiological and biochemical underpinnings of such behavioral shifts. Electrically excitable cells respond to chemicals that alter membrane potential, either through direct interaction with ion channels or by secondary signaling. This in turn leads to calcium fluxes that change ciliary beating, resulting in aggregate changes in swimming speed, orientation and turning frequency, that lead to either attraction or dispersion responses (Kung \& Saimi 1982, Machemer \& Teunis 1996). Like these model ciliates, Favella sp. has the capability for chemosensory responses. For example, Buskey \& Stoecker $(1988,1989)$ showed that Favella sp. decreased swimming speed and increased turning frequency after encountering a prey patch; such changes were also triggered by filtrate from prey cultures in the absence of prey cells. In contrast, our experiments, which used uniformly dispersed signals rather than patches, have not shown any consistent behavioral change in Favella sp. upon exposure to inhibitory DFAAs. We recognize the limitations of 2D analysis of 3D helical motions, which can fail to detect subtle changes. However, average helical swimming speeds and NGDR, a measure of turning frequency, were not different in control treatments vs. treatments containing inhibitory amino acids (Fig. 6). Helical swimming appeared in some experiments to be replaced by start-stop motions in response to inhibitory compounds. However, the time course of the behavioral changes was slower than that of feeding inhibition, and the behavioral changes were not consistent among experiments yielding nearly identical feeding responses.

A further contrast with previous work on ciliates is evident in the adaptation to deterrent signals. When initially exposed to chemorepellents such as lysozyme or GTP, Paramecium showed an increased frequency of swimming reversals and changes of direction, but recovered fully after 10 to 15 min continuous exposure, 
due to desensitization (Kim et al. 1997). In our experiments, Favella sp. feeding rate showed only partial adaptation, and that required $>4 \mathrm{~h}$ rather than minutes to achieve (Fig. 3). Furthermore, removal of inhibitory amino acids only led to partial recovery over $1 \mathrm{~h}$ (Fig. 5), indicating the involvement of multiple mechanisms with different recovery times. Taken together, these observations indicate that the amino acid signaling system in Favella sp. may be fundamentally different from that in other, better-studied ciliates.

Despite these differences, we suspect that amino acid inhibition may result from specific binding to cell ion channels, or to receptors that indirectly affect membrane potential. Another possibility is that DFAAs bind to membranelles and interfere with chemoreception or capture of prey. For example, DFAA binding might inhibit the ciliary reversals associated with capture of large prey, including Heterocapsa triquetra, by Favella sp. (Stoecker et al. 1995). We are currently pursuing studies of amino acid binding to further understand the mechanism of inhibition.

\section{Generality and adaptive significance of the inhibitory effect}

The generality of the amino acid inhibitory response demonstrated by Favella sp. is not clear. The dinoflagellate Gyrodinium dominans showed no feeding response to any added amino acid (data not shown). The tintinnid Coxliella sp. was moderately inhibited by DMSP, betaine, and probably proline (Fig. 8), but showed no response to 2 other amino acids that inhibited Favella sp. However, the Coxliella culture at the time of the experiment was not at the peak of health; control feeding rates were low, and the ciliate was lost from culture soon after the experiment. Sensitivity to chemical signals may be related to physiological condition. Alternatively, compared to Favella sp., Coxliella may be adapted to waters that are chronically higher in DFAA concentration. More research is needed to establish the species-specificity of the inhibitory effect reported here.

One of the most interesting aspects arising from the amino acid response in Favella sp. is its adaptive significance. Considerable evidence (widespread response to amino acids among aquatic organisms, lack of toxicity, environmentally relevant response threshold) supports the idea that amino acids are signal molecules for Favella sp. What is the information content of the signal? Amino acid pulses might indicate the presence of actively feeding zooplankton, which are potential predators on Favella sp. Weissburg et al. (2002) have hypothesized that the use of chemical signals to detect nearby predators is a widespread strat- egy among potential prey organisms. If warned of predators, however, one would expect a behavioral response from Favella sp.: either a reduction in swimming activity to reduce hydromechanical signals that might attract predators, or an active escape response. We saw no consistent indication of a change in swimming behavior upon exposure to inhibitory amino acids. A second possibility is that amino acids signal the proximity of algal (or other) prey, and would attract Favella sp. (as they do many other aquatic organisms), given the appropriate behavioral assay. In this case, one would again expect a behavioral response, e.g. the decreases in swimming speed and increases in turning frequency that have been associated with Favella sp. exposure to prey in previous studies (Buskey \& Stoecker 1988, 1989). Also, it is not clear why feeding would cease in the presence of an attractant. Few, if any, previous studies of chemosensory response in protists have measured feeding rates. Finally, amino acids may signal the presence of low quality or harmful prey. DMSP, betaine, proline, alanine, and possibly other amino acids are produced or accumulated at higher rates under osmotic and oxidative stress (Kaneshiro et al. 1969, Hare et al. 1998, Sharma \& Dietz 2006), and leakage of these compounds from cells might indicate loss of membrane integrity. This hypothesis fits our observation of feeding inhibition without an accompanying behavioral response.

\section{CONCLUSIONS}

Feeding rates in the tintinnid Favella sp. were inhibited by a number of amino acids, with inhibition inversely proportional to the size of the amino acid side chain. Inhibition was dose-dependent, with a threshold in the vicinity of $200 \mathrm{nM}$ of proline, and did not depend on the feeding history (well-fed vs. starved) of Favella sp. Inhibition occurred rapidly $(<5$ min after exposure) and was readily, though not completely, reversible. These findings, along with the prevalence of some inhibitory compounds at nanomolar concentrations in natural waters, point to a signaling function for these amino acids. Amino acid signaling is well known in aquatic systems, but amino acids usually constitute an attractant or stimulatory (rather than inhibitory) cue. Further, in contrast to findings from model ciliates such as Paramecium and Tetrahymena, Favella sp. did not rapidly or completely adapt to the presence of the inhibitory compounds. Nor did the tintinnid show consistent accompanying changes in swimming behavior, although the capacity for behavioral changes in response to chemical cues has been documented in the genus. Data presented here, along with work in progress (Wolfe et al. unpubl. data) indi- 
cate involvement of an amino acid receptor in the transmission of the inhibitory signal. The information content of the signal remains unclear but may be related to detection of prey quality during suspension feeding by Favella sp.

Acknowledgements. We thank H. Jakobson and S. MendenDeuer for assistance with video and track analysis, and acknowledge N. Blackburn (Bioras) for providing LabTrack software and insights into behavior data analysis. H. Jakobsen also provided cultures of Gyrodinium dominans and several of the phytoplankton used in this study. We appreciate the assistance of K. Fredrickson with feeding experiments and statistical analysis, A. Raetz with PERL programming, and C. Rich with behavior data analysis. Thanks also to C. Wolfe and T. Kiser for suggestions on analysis of swimming. This research was supported by National Science Foundation grants OCE 0324352 and 0325025.

\section{LITERATURE CITED}

Andersson A, Lee C, Azam F, Hagström Å (1985) Release of amino acids and inorganic nutrients by heterotrophic marine microflagellates. Mar Ecol Prog Ser 23:99-106

Billen G, Joiris C, Wijant J, Gillain G (1980) Concentration and microbiological utilization of small organic molecules in the Scheldt Estuary, the Belgian coastal zone of the North Sea and the English Channel. Estuar Coast Mar Sci 11:279-294

Birwé H, Hesse A (1991) High-performance liquid chromatographic determination of urinary cysteine and cystine. Clin Chim Acta 199:33-42

Boettcher AA, Targett NM (1998) Role of chemical inducers in larval metamorphosis of queen conch, Strombus gigas Linnaeus: relationship to other marine invertebrate systems. Biol Bull 194:132-142

Buskey EJ, Stoecker DK (1988) Locomotory patterns of the planktonic ciliate Favella sp.: adaptations for remaining within food patches. Bull Mar Sci 43:783-796

Buskey EJ, Stoecker DK (1989) Behavioral responses of the marine tintinnid Favella sp. to phytoplankton: influence of chemical, mechanical and photic stimuli. J Exp Mar Biol Ecol 132:1-16

Carr WES, Netherton JC, Gleeson RA, Derby CD (1996) Stimulants of feeding behavior in fish: analysis of tissues of diverse marine organisms. Biol Bull 190:149-160

Crawford CC, Hobbie JE, Webb KL (1974) The utilization of dissolved free amino acids by estuarine microorganisms. Ecology 55:551-563

Cronkite DL, Diekman AB, Lewallen B, Phillips L (1993) Aminotransferase and the production of alanine during hyperosmotic stress in Paramecium calkinsi. J Eukaryot Microbiol 40:796-800

Csonka LN, Hanson AD (1991) Prokaryotic osmoregulation: genetics and physiology. Annu Rev Microbiol 45:569-606

Ferner MC, Jumars PA (1999) Responses of deposit-feeding spionid polychaetes to dissolved chemical cues. J Exp Mar Biol Ecol 236:89-106

Granum E, Kirkvold S, Myklestad SM (2002) Cellular and extracellular production of carbohydrates and amino acids by the marine diatom Skeletonema costatum: diel variations and effects of $\mathrm{N}$ depletion. Mar Ecol Prog Ser 242:83-94
Hansen G, Daugbjerg N (2004) Ultrastructure of Gyrodinium spirale, the type species of Gyrodinium (Dinophyceae), including a phylogeny of $G$. dominans, G. rubrum, and $G$. spirale deduced from partial LSU rDNA sequences. Protist 155:271-294

Hare PD, Cress WA, Van Staden J (1998) Dissecting the roles of osmolyte accumulation during stress. Plant Cell Environ 21:535-553

Hauser DCR, Levandowsky M, Glassgold JM (1975) Ultrasensitive chemosensory responses by a protozoan to epinephrine and other neurochemicals. Science 190:285-286

Hoch MP, Kirchman DL (1995) Ammonium uptake by heterotrophic bacteria in the Delaware estuary and adjacent coastal waters. Limnol Oceanogr 40:886-897

Ide K, Takahashi K, Nakano T, Sato M, Omori M (2006) Chemoreceptive foraging in a shallow-water scavenging lysianassid amphipod: role of amino acids in the location of carrion in Scopelocheirus onagawae. Mar Ecol Prog Ser 317:193-202

Jakobsen HH, Strom SL (2004) Circadian cycles in growth and feeding rates of heterotrophic protist plankton. Limnol Oceanogr 49:1915-1922

Jørgensen NOG, Jensen RE (1997) Determination of dissolved combined amino acids using microwave-assisted hydrolysis and HPLC precolumn derivatization for labeling of primary and secondary amines. Mar Chem 57: 287-297

Kaneshiro ES, Holz GG Jr, Dunham PB (1969) Osmoregulation in a marine ciliate, Miamiensis avidus. II. Regulation of intraceullular free amino acids. Biol Bull 137:161-169

Kim MY, Kuruvilla HG, Hennessey TM (1997) Chemosensory adaptation in Paramecium involves changes in both repellent binding and the consequent receptor potentials. Comp Biochem Physiol 118A:589-597

Kirst GO (1989) Salinity tolerance of eukaryotic marine algae. Annu Rev Plant Physiol Plant Mol Biol 40:21-53

Kung C, Saimi Y (1982) The physiological basis of taxes in Paramecium. Annu Rev Physiol 44:519-534

Kuznetsova M, Lee C, Aller J, Frew N (2004) Enrichment of amino acids in the sea surface microlayer at coastal and open ocean sites in the North Atlantic Ocean. Limnol Oceanogr 49:1605-1619

Laval-Peuto M (1981) Construction of the lorica in Ciliata Tintinnina. In vivo study of Favella ehrenbergii: variability of the phenotypes during the cycle, biology, statistics, biometry. Protistologica 17:242-279

Lee ES, Lewitus AJ, Zimmer RK (1999) Chemoreception in a marine cryptophyte: behavioral plasticity in response to amino acids and nitrate. Limnol Oceanogr 44:1571-1574

Lee PA, Saunders PA, de Mora SJ, Deibel D, Levasseur M (2003) Influence of copepod grazing on concentrations of dissolved dimethylsulfoxide and related sulfur compounds in the North Water, northern Baffin Bay. Mar Ecol Prog Ser 255:235-248

Levandowsky M, Cheng T, Hehr A, Kim J and 6 others (1984) Chemosensory responses to amino acids and certain amines by the ciliate Tetrahymena: a flat capillary assay. Biol Bull 167:322-330

Liebezeit G, Bolter M, Brown IF, Dawson R (1980) Dissolved free amino acids and carbohydrates at pycnocline boundaries in the Sargasso Sea and related microbial activity. Oceanol Acta 3:357-362

Lindroth P, Mopper K (1979) High performance liquid chromatographic determination of subpicomole amounts of amino acids by precolumn fluorescence derivatization with o-phthaldialdehyde. Anal Chem 51:1667-1672

Machemer H, Teunis PFM (1996) Sensory-motor coupling 
and motor responses. In: Hausmann K, Bradbury X (eds) Ciliates: cells as organisms. Gustav Fischer Verlag, Stuttgart, p 379-402

Marsot P, Cembella AD, Colombo JC (1991) Intracellular and extracellular amino acid pools of the marine diatom Phaeodactylum tricornutum (Bacillariophyceae) grown on unenriched seawater in high-cell-density dialysis culture. J Phycol 27:478-491

Matrai PA, Keller MD (1994) Total organic sulfur and dimethylsulfoniopropionate in marine phytoplankton: intracellular variations. Mar Biol 119:61-68

Miller TR, Hnilicka K, Dziedzic A, Desplats P, Belas R (2004) Chemotaxis of Silicibacter sp. strain TM1040 toward dinoflagellate products. Appl Environ Microbiol 70: 4692-4701

Miyamoto S, Shimozawa A (1985) Chemotaxis in the freshwater planarian, Dugesia japonica japonica. Zool Sci 2: 389-395

Mopper K, Lindroth P (1982) Diel and depth variations in dissolved free amino acids and ammonium in the Baltic Sea determined by shipboard HPLC analysis. Limnol Oceanogr 27:336-347

Murphy BF, Hadfield MG (1997) Chemoreception in the nudibranch gastropod Phestilla sibogae. Comp Biochem Physiol 118A:727-735

Nagata T, Kirchman DC (1991) Release of dissolved free and combined amino acids by bactivorous marine flagellates. Limnol Oceanogr 36:433-443

Parsons TR, Maita Y, Lalli CM (1984) A manual of chemical and biological methods for seawater analysis. Pergamon, Oxford

Pasmore M, Costerton JW (2003) Biofilms, bacterial signaling, and their ties to marine biology. J Ind Microbiol Biotechnol 30:407-413

Pierce RW, Turner JT (1993) Global biogeography of marine tintinnids. Mar Ecol Prog Ser 94:11-26

Poulet SA, Ouellet G (1982) The role of amino acids in the chemosensory swarming and feeding of marine copepods. J Plankton Res 4:341-361

Poulet SA, Williams R, Conway DVP, Videau C (1991) Cooccurence of copepods and dissolved free amino acids in shelf sea waters. Mar Biol 108:373-385

Rice MA (1999) Uptake of dissolved free amino acids by northern quahogs, Mercenaria mercenaria and its relative importance to organic nitrogen deposition in Naragansett Bay, Rhode Island. J Shellfish Res 18:547-553

Riffell JA, Krug PJ, Zimmer RK (2002) Fertilization in the sea: the chemical identity of an abalone sperm attractant. J Exp Biol 205:1439-1450

Rosenstock B, Simon M (2001) Sources and sinks of dissolved free amino acids and protein in a large and deep mesotrophic lake. Limnol Oceanogr 46:644-654

Rublee PA, Gallegos CL (1989) Use of fluorescently labelled algae (FLA) to estimate microzooplankton grazing. Mar Ecol Prog Ser 51:221-227

Sellner KG, Nealley EW (1997) Diel fluctuations in dissolved free amino acids and monosaccharides in Chesapeake Bay

Editorial responsibility: Fereidoun Rassoulzadegan, Villefranche-sur-Mer, France dinoflagellate blooms. Mar Chem 56:193-200

Sharma SS, Dietz KJ (2006) The significance of amino acids and amino acid-derived molecules in plant responses and adaptation to heavy metal stress. J Exp Bot 57:711-726

Sibbald MJ, Albright LJ, Sibbald PR (1987) Chemosensory responses of a heterotrophic microflagellate to bacteria and several nitrogen compounds. Mar Ecol Prog Ser 36: 201-204

Simon M, Grossart HP, Schweitzer B, Ploug H (2002) Microbial ecology of organic aggregates in aquatic ecosystems. Aquat Microb Ecol 28:175-211

Spero HJ (1985) Chemosensory capabilities in the phagotrophic dinoflagellate Gymnodinium fungiforme. J Phycol 21:181-184

Stoecker DK, Gallager SM, Langdon CJ, Davis LH (1995) Particle capture by Favella sp. (Ciliata, Tintinnina). J Plankton Res 17:1105-1124

Strom SL, Benner R, Ziegler S, Dagg MJ (1997) Planktonic grazers are a potentially important source of marine dissolved organic carbon. Limnol Oceanogr 42:1364-1374

Strom SL, Wolfe GV, Slajer A, Lambert S, Clough J (2003) Chemical defense in the microplankton II: Inhibition of protist feeding by $\beta$-dimethylsulfoniopropionate. Limnol Oceanogr 48:230-237

Sunda WG, Kieber DJ, Kiene RP, Huntsman SA (2002) An antioxidant function for DMSP and DMS in marine algae. Nature 418:317-320

Valentincic T (1985) Behavioral study of chemoreception in the sea star Marthasterias glacialis: structure-activity relationships of lactic acid, amino acids, and acetylcholine. J Comp Physiol A 157:537-545

Van Houten J (1978) Two mechanisms of chemotaxis in Paramecium. J comp Physiol 127:167-174

Vardi A, Formiggini F, Casotti R, De Martino A, Ribalet F, Miralto A, Bowler C (2006) A stress surveillance system based on calcium and nitric oxide in marine diatoms. PLOS Biology 4:411-419

Weissburg MJ, Ferner MC, Pisut DP, Smee DL (2002) Ecological consequences of chemically mediated prey perception. J Chem Ecol 28:1953-1970

Wolfe GV (2000) The chemical defense ecology of marine unicellular plankton: constraints, mechanisms, and impacts. Biol Bull 198:225-244

Wolfe GV, Strom SL, Holmes JL, Radzio T, Olson MB (2002) Dimethylsulfoniopropionate cleavage by marine phytoplankton in response to mechanical, chemical, or dark stress. J Phycol 38:948-960

Yang H (1995) Distribution of free amino acids in sea and lake ice cores from Antarctica with special reference to ice biota. Proc Natl Inst Polar Res Symp Polar Biol 8:114-125

Zimmer RK, Commins JE, Browne KA (1999) Regulatory effects of environmental chemical signals on search behavior and foraging success. Ecology 80:1432-1446

Zimmer-Faust RK, Tamburri MN (1994) Chemical identity and ecological implications of a waterborne, larval settlement cue. Limnol Oceanogr 39:1075-1087

Submitted: November 20, 2006; Accepted: February 19, 2007 Proofs received from author(s): April 30, 2007 